\title{
THE COPPER INTERFERENCE WITH THE MELANOGENESIS OF Cryptococcus neoformans
}

\author{
Renan Marrichi MAUCH(1), Vinícius de Oliveira CUNHA(1) \& Amanda Latercia Tranches DIAS(1)
}

\begin{abstract}
SUMMARY
Melanin is a pigment produced by laccase, a phenoloxydase enzyme, and is related to the virulence of Cryptococcus neoformans as it is also considered an adaption mechanism to environmental conditions and protection against UV radiation, phagocytic system attack and antifungal drugs. Laccase synthesis is stimulated by several factors, including copper metabolism. The current study shows C. neoformans strains with higher melanization intensity when grown in L-dopa medium supplemented with different concentrations of copper sulfate. This increase shows that melanization rates may be enhanced in the presence of copper ions and may also enhance the virulence of $C$. neoformans in infected patients that present increasing copper concentrations in serum, such as those with HIV. The virulence of these strains may also be increased in the environment, where this metal is available as $\mathrm{CuSO}_{4}$ in algicidal and fungicidal compounds.
\end{abstract}

KEYWORDS: Cryptococcus neoformans; Melanin; Copper; Virulence.

\section{INTRODUCTION}

Cryptococcosis is a systemic mycosis caused by the encapsulated yeast Cryptococcus neoformans and provokes severe infectious conditions in immunocompromised patients. Among its predisposing causes, organ transplants, lymphoproliferative diseases, treatment with lymphoblastic and corticoid drugs, and mainly HIV infections, are the most common. Usually it affects the human central nervous system due to the neurotropism of the yeast, causing meningoenchephalitis. Cryptococcosis can also affect the pulmonary system and be aggravated, getting to the central nervous system ${ }^{3}$.

Cryptococcus neoformans produces an enzyme called laccase, a phenoloxydase related to melanization in the cells, which is considered one of the most important factors associated with virulence ${ }^{4,19}$. ZHU et al., $2001^{22}$ showed that laccase is strongly associated to the cell wall of C. neoformans, which enables this enzyme to have maximum access to substrates of the host cell in its mechanism as a modulator of immune response in the host. Melanized cells are usually less susceptible to antimicrobial drugs and oxidant agents; in addition they are able to trick the host immune system by inactivating the drugs normally used on therapeutics. Melanin synthesis occurs due to oxidative polimerization of phenolic compounds ${ }^{16}$. Melanin production has warranted attention because studies have proven the relationship between its expression level and virulence, since samples with elevated virulence have presented the characteristic of producing higher amounts of melanin ${ }^{2}$, and these samples became less virulent when the gene related to melanin production had been destroyed. In environmental conditions, melanin protects the yeast against enzymatic degradation by other microorganisms, because the yeast becomes less susceptible to the action of hydrolytic enzymes, the action of oxidant agents, extreme temperature, UV radiation ${ }^{15}$, heavy metals ${ }^{9}$ and predator agents like amoebas ${ }^{17}$.

Laccase is composed of four copper ions ${ }^{23}$. Copper is a transition metal and a vital element of redox reactions in the organism since it gains and it loses electrons readily, which also causes it to become potentially toxic ${ }^{1}$. Copper participates in diverse functions in the organism, being an essential element for the immune, nervous and cardiovascular systems, as well for the maintenance of bone health. It is a component in a wide variety of enzymes and proteins that redeem fundamental biological functions to the cell and contribute to the maintenance of its homeostasis ${ }^{8}$. Copper level is enhanced in immunocompromised patients infected by HIV ${ }^{13,14}$. Copper is known to be an acute phase reactant and its levels in serum have been shown to change significantly in a range of acute and chronic infective, inflammatory and neoplastic processes. This metal is believed to be important in maintaining immune function ${ }^{18}$ and is predictive of the progression of disease because its serum level varies between HIV-seronegative and seropositive patients. MORENO et al. ${ }^{14}$ found that seropositive individuals with certain associated symptoms had significantly higher serum copper levels than those measured in HIVinfected subjects of groups without any associated symptoms, meaning that the serum copper enhancement produced by the virus action ${ }^{10}$ is additionally reinforced by the associated diseases. 
In this study, the copper interference with the melanogenesis of $C$. neoformans was evaluated in culture media containing copper ions in different concentrations. In experiments with medium containing L-dopa, a laccase substrate ${ }^{6}$, copper sulfate was added in different concentrations and the yeast cultures showed a higher melanization intensity compared to the control medium (without the presence of copper sulfate) $(p<0.05)$. Clinical and environmental samples showed a large difference, pointing to the fact that the presence of copper at the growth site of the samples can lead to an increase in melanization, and consequently to an enhanced virulence of C. neoformans.

\section{MATERIAL AND METHODS}

Analyzed Samples. Six C. neoformans samples were selected for testing (Table 1): three samples from clinical origin, two samples from environmental origin and a standard sample (ATCC 90112). All of them are maintained in the Mycological Collection of the Laboratory of Microbiology in the Federal University of Alfenas, Brazil (Table 1). The choice was made based on previous results for the virulencerelated factors of some yeasts like phospholipase, proteinase, lipase and superoxide dismutases (data not shown) and an antifungal susceptibility profile (data not shown).

Table 1

C. neoformans samples and description of source and isolation site

\begin{tabular}{lll}
\hline Sample & Source & Isolation site \\
\hline ATCC 90112 (standard) & Clinical & United States \\
ICB 161 & Clinical & São Paulo/SP, Brazil \\
HNR 41 & Clinical & Florianópolis/SC, Brazil \\
VPBet & Clinical & Porto Alegre/RS, Brazil \\
C1 & Environmental & Alfenas/MG, Brazil \\
B02 & Environmental & Rio de Janeiro/RJ, Brazil \\
\hline
\end{tabular}

Melanogenesis index at presence and absence of copper. The cells were grown in Sabouraud Dextrose Agar medium supplied with 2\% yeast extract, at $30^{\circ} \mathrm{C}$ for 48 hours, and then transferred to L-dopa Agar medium (dopamine $0.04 \mathrm{~g} \mathrm{~L}^{-1}$, asparagin $1 \mathrm{~g} \mathrm{~L}^{-1}$, creatinin $0.3 \mathrm{~g} \mathrm{~L}^{-1}$, glutamine $1 \mathrm{~g} \mathrm{~L}^{-1}$, glicine $1 \mathrm{~g} \mathrm{~L}^{-1}$, Magnesium sulfate $2.5 \mathrm{~g} \mathrm{~L}^{-1}$, Potassium phosphate monobasic $5 \mathrm{~g} \mathrm{~L}^{-1}$, glucose $5 \mathrm{~g} \mathrm{~L}^{-1}$, thiamine $0.001 \mathrm{~g} \mathrm{~L}^{-1}$, chloramphenicol $0.2 \mathrm{~g} \mathrm{~L}^{-1}$, agar $22 \mathrm{~g} \mathrm{~L}^{-1}$ ) added to copper sulfate concentrations of $5 \mu \mathrm{M}$, $20 \mu \mathrm{M}, 100 \mu \mathrm{M}, 200 \mu \mathrm{M}$, and a medium without copper sulfate was used as a control. The assays were performed according to the methodology of JIANG et al., $2009^{11}$ with some modifications. The cells were grown in these media for 72 hours and presented different melanization intensities. An arbitrary scale of melanization level was selected to interpret the results, as follows: level 1: absence of melanization; level 2: beige pigmentation; level 3: light brown pigmentation; level 4: medium brown pigmentation and level 5: dark brown pigmentation. The level zero was also used to indicate absence of growth. Each sample was run in duplicate on five different days.

Data analysis. The one-way ANOVA was performed to determine whether there was a significant difference in melanin production in the presence and absence of copper sulfate. Differences of $p<0.05$ were considered significant.

\section{RESULTS}

Growing the cells in L-dopa Agar, increasing levels of strain melanization $(p<0.05)$ were observed in the media containing copper sulfate in concentrations of $5 \mu \mathrm{M}, 20 \mu \mathrm{M}, 100 \mu \mathrm{M}$ and $200 \mu \mathrm{M}$ (Fig. 1 and 2). The melanization level below copper sulfate $5 \mu \mathrm{M}$ was evaluated but the rate was lower than in those other concentrations (data not shown).

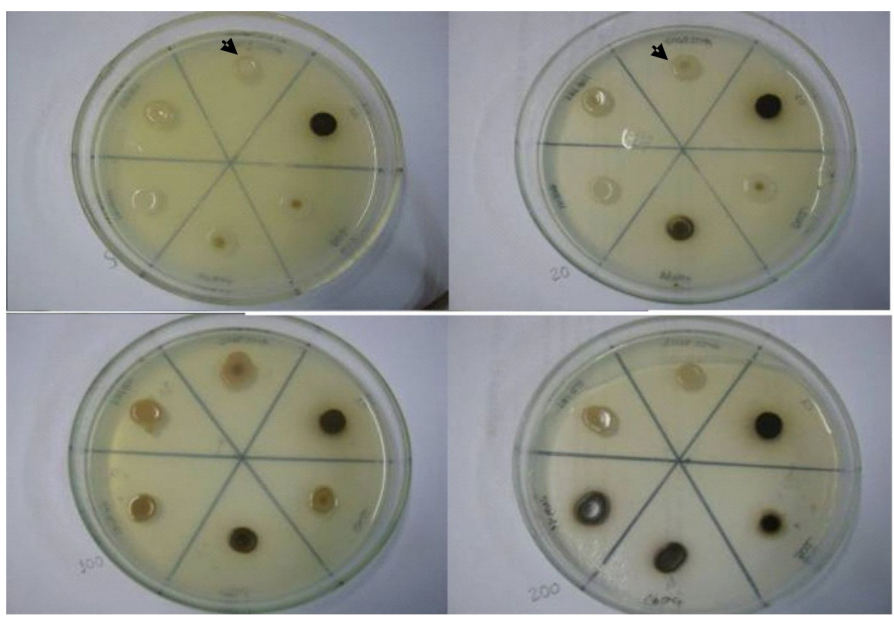

Fig. 1 - Melanization of $C$. neoformans samples growing in L-dopa Agar added with concentrations of $\mathrm{CuSO}_{4}$ (left to right: $5 \mu \mathrm{M}, 20 \mu \mathrm{M}, 100 \mu \mathrm{M}$ and $200 \mu \mathrm{M}$ ). Clockwise direction from the arrows: Samples ATCC 90112, C1, B02, VPBet, HNR 41 and ICB 161.

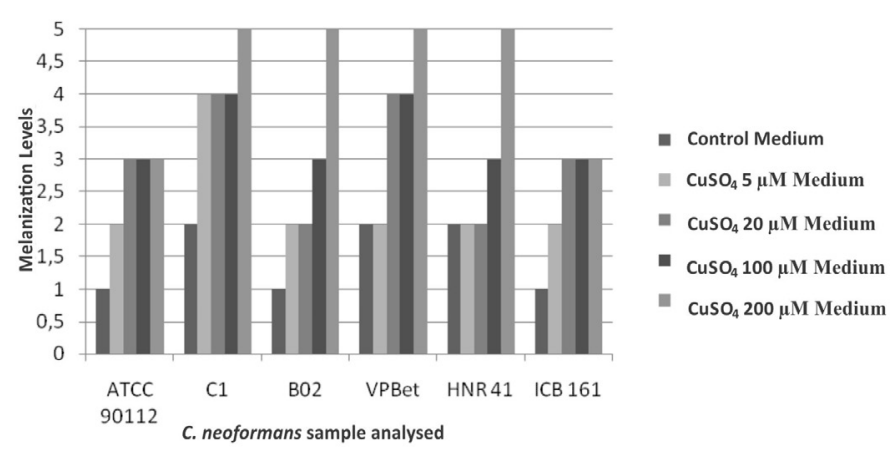

Fig. 2 - Melanization levels in the C. neoformans cells grown in the presence and abscence of $\mathrm{CuSO}_{4}$ concentrations. *the melanization index is a median of ten individual experiments.

The standard strain ATCC 90112 and the clinical sample ICB 161 did not exceed a level 3 of melanization, even when grown in the medium with the maximum copper sulfate concentration. On the other hand, the other strains have detached. The clinical sample VPBet began to present a melanization level 4 when grown in medium with $5 \mu \mathrm{M}$ copper sulfate, and reached a level 5 when grown in the presence of $200 \mu \mathrm{M}$ copper sulfate. The environmental sample $\mathrm{C} 1$, isolated from bird droppings, presented a melanization level 4 when grown in $20 \mu \mathrm{M}$ copper sulfate, reaching a level 5 in $200 \mu \mathrm{M}$ copper sulfate. The samples HNR 41 and B02 still presented melanization level 3 in medium containing $100 \mu \mathrm{M}$ and $200 \mu \mathrm{M}$ copper sulfate. 


\section{DISCUSSION}

Experiments studying metal activity on yeasts are few and very recent. In this report, we showed that melanization rates can be enhanced when exogenous copper is present in the culture. When the samples grown in L-dopa Agar were added to increasing concentrations of copper sulfate, melanization level increased in comparison to the control medium, both in clinical and environmental samples. This is reinforced due the fact that even though these media contain glucose that is an inhibitor of laccase activity, the melanization still occurred regardless of the presence of this glucose in the medium. These results corroborate those obtained by the group of JIANG, 2009 ${ }^{11}$, which was the pioneer study showing that laccase activity is induced by high exogenous copper concentrations. In that study, mRNA amplification of the LAC1 gene by RT-PCR revealed that laccase induction occurred at a transcriptional level, which required the codifying gene of CUF1 copper-responsive factor, whose interruption inhibited LAC1 transcription activation by copper. Previously, WATERMAN et al., $2007^{21}$ had shown that CUF1 deletion impaired $C$. neoformans growth, and in experiments in vivo they showed that CUF1-deficient strains presented reduced dissemination to the brain, but did not present changes to growth in the lungs. They also showed that the CUF1 transporter gene (CTR4) presented a higher expression in conditions of copper starvation. CHUN \& MADHANI, $2010^{5}$ showed that a mutagenesis in the encoder gene of the copper transporter CTR2 caused susceptibility to copper starvation in the C. neoformans strain, which became deficient in its transport. Moreover, the strain also presented defects in capsule formation, being more susceptible to phagocytic activity. This suggests a link between copper homeostasis and capsule formation in $C$. neoformans.

Previously, JIANG et al., $2009^{11}$ found that CUF1 negatively regulates the capsule, an important factor related to $C$. neoformans virulence. Another study by JIANG et al., $2011^{12}$ showed that CUF1 was involved both in copper acquisition and detoxification in response to copper excess, suggesting that CUF1 can also function as a copper exporter.

The results obtained here support the aforementioned studies. In general, all the samples showed a greater or lesser increase in the production of their main virulence-related factor: the melanin pigment, in medium containing copper sulfate. The environmental samples $(\mathrm{C} 1$ and B02) showed a higher melanization level in the presence of copper sulfate concentrations. The same happened to the clinical samples, but the sample ICB 161 did not present a melanization level greater than 3 even when grown in medium containing the highest copper sulfate concentration $(200 \mu \mathrm{M})$.

With these data, it can be suggested that laccase is more active when the yeast is in the presence of increasing concentrations of copper sulfate. Since the serum copper level is enhanced in immunocompromised patients ${ }^{13}$ and cryptococcosis is an opportunistic mycosis, a correlation between copper level and an increased virulence of the yeast may be suggested. C. neoformans is viable on soil, so already an increase in virulence on the environment strains can also be suggested. Certain fertilizers used on soil, besides being antimicrobial agents working as fungicides and algaecides, have copper sulfate in their composition, so they can contribute to the increase in virulence of $C$. neoformans.

On the other hand, the positive influence of copper on the growth and virulence of $C$. neoformans goes against results obtained by recent reports. FREETH, 20117 , in a clinical assay in various locations in the United States, showed that copper surfaces in rooms of intensive care units led to a $40.4 \%$ reduction in the risk of contracting a hospital infection, and these copper surfaces avoided the appearing of antimicrobial resistant microorganisms. WARNES et al., 2010 ${ }^{20}$ showed that copper alloys have efficient biocide action against pathogenic bacterias from the Enterococcus genus, and such action involves chromosomal and plasmidic DNA degradation in these bacterias.

Nowadays, when studies about virulence factors in microorganisms are the key to discovering new therapeutics, the current study supports the fact that laccase is a good target enzyme for antifungal drugs used to treat infections caused by $C$. neoformans. Further studies are necessary in order to research and clarify these virulence-related factors and routes, with a view to improving the treatment for cryptococcosis.

\section{RESUMO}

\section{A interferência de cobre na melanogênese de Cryptococcus neoformans}

A melanina é um pigmento produzido pela enzima lacase, uma fenoloxidase, e está associada à virulência de Cryptococcus neoformans sendo considerada mecanismo de adaptação às condições ambientais e proteção contra a radiação $U V$, ataque do sistema fagocítico e antifúngicos. A lacase tem sua síntese estimulada por diversos fatores, incluindo o metabolismo de cobre. Este estudo mostra linhagens de $C$. neoformans com maior intensidade de melanização quando cultivadas em meio L-dopa suplementado com diferentes concentrações de sulfato de cobre. Este aumento demonstra que as taxas de melanização podem ser aumentadas na presença de íons cobre e também aumentar a virulência de $C$. neoformans em pacientes infectados que apresentam aumento nas concentrações séricas de íons cobre tais como pacientes com HIV. A virulência destas linhagens também pode ser incrementada no meio ambiente, onde este metal está disponível como $\mathrm{CuSO}_{4}$ em compostos algicidas e fungicidas.

\section{ACKNOWLEDGMENTS}

The Fundação de Amparo à Pesquisa do Estado de Minas Gerais (APQ-01684/08 e 02782/10) and the Universidade de São Paulo for providing us with the samples.

\section{REFERENCES}

1. Askwith C, Kaplan J. Iron and copper transport in yeast and its relevance to human disease. Trends Biochem Sci. 1998;23:135-8

2. Blackstock R, Buchanan KL, Cherniak R, Mitchell TG, Wong B, Bartiss A, et al Pathogenesis of Cryptococcus neoformans is associated with quantitative differences in multiple virulence factors. Mycopathologia. 1999;147:1-11.

3. Casadevall A, Perfect JR. Cryptococcus neoformans. Washington: ASM Press; 1998

4. Casadevall A, Rosas AL, Nosanchuk, JD. Melanin and virulence in Cryptococcus neoformans. Curr Opin Microbiol. 2000;3:354-8.

5. Chun CD, Madhani HD. Ctr2 links copper homeostasis to polyssaccharide capsule formation and phagocytosis inihibition in the human fungal pathogen Cryptococcus neoformans. PloS One. 2010;5:e12503. 
6. Einsenman HC, Mues M, Weber SE, Frases S, Chaskes S, Gerfen G, et al. Cryptococcus neoformans laccase catalyses melanin synthesis from both D- and L-DOPA. Microbiology. 2007;153(P112): 3954-62.

7. Freeth S. Copper surfaces cut hospital infection risk. Aust Nurs J. 2011;19:43.

8. Gaetke LM, Chow CK. Copper toxicity, oxidative stress, and antioxidant nutrients. Toxicology. 2003;189:147-63.

9. Garcia-Rivera J, Casadevall A. Melanization of Cryptococcus neoformans reduces its susceptibility to the antimicrobial effects of silver nitrate. Med Mycol. 2001;39:353-7.

10. Graham NM, Sorensen D, Odaka N, Brookmeyer R, Chan D, Willett WC, et al. Relationship of serum copper and zinc levels to HIV-1 seropositivity and progression to AIDS. J Acquir Immune Defic Syndr. 1991;4:976-80

11. Jiang N, Sun N, Xiao D, Pan J, Wang Y, Zhu X. A copper-responsive factor gene CUF1 is required for copper induction of laccase in Cryptococcus neoformans. FEMS Microbiol Lett. 2009;296:84-90.

12. Jiang N, Liu X, Yang J, Li Z, Pan J, Zhu X. Regulation of copper homeostasis by Cuf1 associates with its subcellular localization in the pathogenic yeast Cryptococcus neoformans H99. FEMS Yeast Res. 2011;11:440-8.

13. Jiménez-Expósito MJ, Bulló Bonet M, Alonso-Villaverde C, Serrano P, GarcíaLorda P, García-Luna PP, et al. Micronutrientes en la infección por el vírus de la immunodeficiencia humana y su relación con la respuesta inflamatória. Med Clin (Barc).2002;119:765-9.

14. Moreno T, Artacho R, Navarro M, Pérez A, Ruiz-López MD. Serum copper concentration in HIV-infection patients and relationships with other biochemical indices. Sci Total Environ. 1998;217:21-6.
15. Rosas AL, Casadevall A. Melanization affects susceptibility of Cryptococcus neoformans to heat and cold. FEMS Microbiol Lett. 1997;153:265-72.

16. Steenbergen JN, Casadevall A. The origin and maintenance of virulence for the human pathogenic fungus Cryptococcus neoformans. Microbes Infect. 2003;5:667-75.

17. Steenbergen JN, Shuman HA, Casadevall A. Cryptococcus neoformans interactions with amoebae suggest an explanation for its virulence and intracellular pathogenic strategy in macrophages. Proc Natl Acad Sci USA. 2001;98:15245-50.

18. Turnlund JR. Copper nutriture, bioavailability, and the influence of dietary factors J Am Diet Assoc. 1988;88:303-8.

19. Wang Y, Aisen P, Casadevall A. Cryptococcus neoformans melanin and virulence: mechanism of action. Infect Immun. 1995;63:3131-6.

20. Warnes SL, Green SM, Michels HT, Keevil CW. Biocidal efficacy of copper alloys against pathogenic enterococci involves degradation of genomic and plasmid DNAs. Appl Environ Microbiol. 2010;76:5390-401.

21. Waterman S, Hacham M, Hu G, Zhu X, Park YD, Shin S, et al. Role of a CUF1/ CTR4 copper regulatory axis in the virulence of Cryptococcus neoformans. J Clin Invest. 2007;117:794-802.

22. Zhu X, Gibbons J, Garcia-Rivera J, Casadevall A, Williamson PR. Laccase of Cryptococcus neoformans is a cell wall-associated virulence factor. Infect Immun. 2001;69:5589-96.

23. Zhu X, Williamson PR. Role of laccase in the biology and virulence of Cryptococcus neoformans. FEMS Yeast Res. 2004;5:1-10.

Received: 3 May 2012

Accepted: 28 August 2012 